\title{
Interaction between Meloidogyne javanica and Ralstonia solanacearum in Chili
}

\author{
Ali Asghar ${ }^{1 *}$, Tariq Mukhtar ${ }^{1}$, Muhammad Usman Raja ${ }^{1}$ and Asim Gulzar ${ }^{2}$ \\ ${ }^{1}$ Department of Plant Pathology, Pir Mehr Ali Shah Arid Agriculture University, \\ Rawalpindi, Pakistan \\ ${ }^{2}$ Department of Entomology, Pir Mehr Ali Shah Arid Agriculture University, \\ Rawalpindi, Pakistan
}

\section{A B S T R A C T}

The information on the interaction between root-knot nematodes and bacterial wilt is lacking in chili, therefore, in the present study, effects of Meloidogyne javanica and Ralstonia solanacearum were studied on chili singly and in combinations. Significant effects of $M$. javanica and $R$. solanacearum and their interaction were observed in case of shoot and root lengths and weights of chili. The mean lengths and weights of shoot and root varied significantly as a result of both the pathogens applied singly and in combinations. The reductions in these parameters were significantly higher when both the pathogens were applied simultaneously as compared to their sole applications. Similarly, at higher inoculum densities, the reductions were the maximum in all these parameters. Significant variations were observed in number of galls and egg masses per root system in response to both the pathogens applied individually and in combinations. Maximum numbers of galls and egg masses were observed where nematode was applied alone. Significant reductions in galls and egg masses were recorded where nematode and the bacterium were applied in combinations. At higher densities of both the pathogens, the reductions in these parameters were the maximum. The first wilt appearance was observed after 8 days in the treatment where both the pathogens were applied at their highest densities. The treatments where bacterium was applied individually at different densities, wilt took maximum days to appear as compared to the treatments where bacterium and nematodes were applied in combinations. Similarly, the incidence of bacterial wilt was lower where the nematode was absent. Minimum wilt incidence was recorded at the lowest density of $R$. solanacearum. The wilt incidence increased significantly when nematode was inoculated along with the bacterium and maximum incidence was recorded where both the pathogens were applied at their highest densities.
\end{abstract}
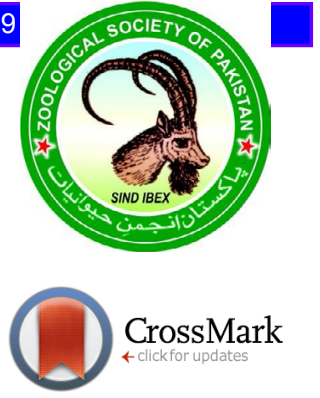

\section{INTRODUCTION}

$\mathrm{D}$ fferent kinds of phytopathogenic bacteria including Clavibacter michiganensis subsp. michiganensis, $C$. michiganensis subsp. insidiosus, C. michiganensis subsp. nebraskensis, Erwinia trachiophila, Pantoeaste wartii are the causal organisms of bacterial wilt in different types of plants. Among all these, Ralstonia solanacearum inciting bacterial wilt disease has caused significant yield losses and has achieved an alarming position in chili growing areas. The low yield of chili is attributable to a number of biotic factors including insect pests (Javed et al., 2017a, b, 2019; Aslam et al., 2019a), fungi (Fateh et al., 2017), viruses (Ashfaq et al., 2017), nematodes (Kayani et al., 2017, 2018; Khan et al., 2017; Mukhtar et al., 2017a; Mukhtar, 2018) and particularly the bacteria (Aslam et al., 2019b).

$R$. solanacearum has wide geographic distribution and host range (Hayward, 1994) and infects more than

\footnotetext{
* Corresponding author: ali.asghar24@ymail.com 0030-9923/2020/0004-1525 \$9.00/0

Copyright 2020 Zoological Society of Pakistan
}

451 plant species from 54 botanical families (Wicker et al., 2007). The pathogen invades xylem as vascular inhibiting bacteria. The pathogen is dispersed by different means viz. irrigation water, budding, grafting, ornamental tubers, potatoes, vegetables and banana (Flores-Cruz and Allen, 2009) but the most damaging source of dispersal is waterways (Elphinstone, 2005). The bacterium enters through natural openings and moves towards the xylem vessels where it blocks the supply of minerals and water and causes vascular browning, yellowing and stunting in many plants (Smith, 1920; Sarkar and Chaudhuri, 2015). Other symptoms include narrow dark strips beneath the epidermis, growth of adventitious roots on the stem, epinasty beneath the leaves, and oozing of bacteria in the form of slimy material when the infected stem is cut (Sarkar and Chaudhuri, 2015). The bacterium causes bacterial wilt which is a destructive disease of many plants and has caused significant yield losses in solanaceous crops worldwide (Yabuuchi et al., 1995; Hayward et al., 2005). In European Union it is considered as a quarantine pest and a potential bioterrorism agent in USA (Lambert, 2002). 
The first evidence of this disease in Pakistan was recorded during the year 1989 (Geddes, 1989). Later on Burney et al. (1999) investigated this pathogen in main solanaceous crops growing areas of Sindh and Punjab of Pakistan and recorded its incidence and severity. The pathogen spread with irrigation and rain water and moon soon (rainy season) played a significant role in the dispersal of this pathogen and chili is heavily attacked by this pathogen during this season. The attack was visible with wilting and caused heavy yield losses in chili crop.

The incidence and severity of bacterial wilt increased when root-knot nematodes were found present conjointly with $R$. solanacearum in many vegetables (Tariq-Khan et al., 2017; Kayani and Mukhtar, 2018; Mukhtar et al., 2018; Hussain and Mukhtar, 2019). It has been known for a long time that root-knot nematodes facilitate entry and establishment of pathogenic fungi and bacteria (Powell, 1971). In brinjal, the disease complex has been observed frequently involving $R$. solanacearum and root-knot nematode contributing to an increase in wilt development (Swain et al., 1987).

The information on the interaction between root-knot nematodes and bacterial wilt is lacking in chili, therefore in the present study effects of Meloidogyne javanica and $R$. solanacearum were studied on chili singly and in combinations.

\section{MATERIALS AND METHODS}

\section{Bacterial culture}

A highly virulent isolate of $R$. solanacearum commonly prevalent in Pakistan was used in the studies. The bacterium was isolated from diseased plants showing typical bacterial wilt symptoms, confirmed immunologically and purified from a single colony. The hypersensitive reaction was performed on tobacco and tomato plants and pathogenicity was confirmed on susceptible cultivars of tomato and tobacco. After molecular confirmation, the purified culture of the highly virulent isolate was prepared and adjusted to $10^{5}, 10^{6}$ and $10^{7} \mathrm{cfu} / \mathrm{ml}$ (Aslam et al., 2017a, b).

\section{Nematode inoculum}

A purified culture of $M$. javanica initiated by a single egg mass and propagated on tomato cv. Money maker was used in the experiment. Twenty four hours old second stage juveniles (J2s) of the nematode were extracted by following the method described by Whitehead and Hemming (1965), standardized, concentrated and used for inoculation of chili plants.
Raising of chili nursery

The nursery of chili cv Bahawalpur Desi moderately resistant to bacterial wilt (Aslam et al., 2017a) was raised in sterilized potting mixture in germination trays in the greenhouse. The daily temperature of the greenhouse ranged $25-27^{\circ} \mathrm{C}$. The trays were watered when required.

Assessment of R. solanacearum and $\mathrm{M}$. javanica on chili

The effects of $R$. solanacearum and M. javanica were assessed on chili in polythene bags measuring $12.75 \times 10.15 \mathrm{~cm}$. The bags were filled with sterilized soil containing 3:1:1 sand, silt and compost respectively. Three week old seedlings of chili cv Bahawalpur Desi were transferred individually to polythene bags. One week after transplantation, the plants were inoculated with $M$. javanica (a) 0, 1000 and $2000 \mathrm{~J} 2 \mathrm{~s}$ per plant and $R$. solanacearum (a) $0,10^{5}, 10^{6}$ and $10^{7} \mathrm{cfu} / \mathrm{ml}$ singly and in combinations. There were six replications for each treatment. The bags were arranged randomly in a glasshouse at a temperature of $25^{\circ} \mathrm{C}$ for six weeks and were properly moistened at alternative days.

\section{Data collection}

After inoculation, the wilt symptoms and wilted plants were recorded and graded with disease rating scale of 0-5 (Winstead and Kelman, 1952). The plants were gently removed from their respective pots after a period of six weeks. The shoots were excised from the roots and their lengths and weights were measured. The galls and egg masses of the whole root systems of plants were counted under stereoscope at magnification of $40 \times$.

\section{Statistical analysis}

The experiment was conducted using completely randomized design. Percent reductions in growth parameters were calculated over controls prior to statistical analysis (Mukhtar et al., 2017b). All the data were analyzed statistically employing GenStat software $12^{\text {th }}$ edition (version 12.1.0.3278) and two way analysis of variance was performed. For comparison among means for significant differences, Fisher's protected least significant difference test was used at $(\mathrm{P} \leq 0.05)$.

\section{RESULTS}

\section{Effect on growth parameters of chili}

Significant effects of $M$. javanica and $R$. solanacearum and their interaction were observed in case of shoot and root lengths and weights of chili. The mean lengths and weights of shoot and root varied significantly as a result of both the pathogens applied singly and in combinations. The reductions in these parameters were significantly higher 
when both the pathogens were applied simultaneously as compared to their sole applications. Similarly, at higher inoculum densities, the reductions were the maximum in all these parameters as shown in Table I.

Table I. Effect of Ralstonia solanacearum and Meloidogyne javanica on percent reduction in shoot length, root length, shoot weight and root weight and number of galls and number of egg masses on chilli roots. The table also shows wilt free days of chilli and incidence of bacterial wilt after 42 days.

\begin{tabular}{|c|c|c|c|c|}
\hline \multirow{2}{*}{$\begin{array}{l}\text { Meloidogyne ja- } \\
\text { vanica }\left(\mathrm{J} 2 \mathrm{~s} \mathrm{K \textrm {Kg } ^ { - 1 }}\right)\end{array}$} & \multicolumn{4}{|c|}{ Ralstonia solanacearum $\left(\mathrm{cfu} \mathrm{ml}^{-1}\right)$} \\
\hline & 0 & $\times 10^{5}$ & $1 \times 10^{6}$ & $1 \times 10^{7}$ \\
\hline \multicolumn{5}{|l|}{ Shoot length } \\
\hline 0 & 0.00 & 5.56 & 14.81 & 18.15 \\
\hline 1000 & 11.85 & 17.78 & 23.33 & 25.93 \\
\hline 2000 & 23.33 & 25.56 & 29.26 & 30.74 \\
\hline \multicolumn{5}{|l|}{ Root length } \\
\hline 0 & 0.00 & 7.91 & 11.8 & 19.24 \\
\hline 1000 & 8.33 & 12.84 & 13.7 & 20.6 \\
\hline 2000 & 11.17 & 21.24 & 23.4 & 26.17 \\
\hline \multicolumn{5}{|l|}{ Shoot weight } \\
\hline 0 & 0.00 & 6.22 & 10.62 & 12.36 \\
\hline 1000 & 7.48 & 11.34 & 13.83 & 15.98 \\
\hline 2000 & 11.48 & 15.14 & 19.41 & 20.68 \\
\hline \multicolumn{5}{|l|}{ Root weight } \\
\hline 0 & 0.00 & 6.78 & 9.56 & 16.38 \\
\hline 1000 & 7.21 & 10.62 & 11.48 & 18.16 \\
\hline 2000 & 9.35 & 13.83 & 16.36 & 21.24 \\
\hline \multicolumn{5}{|c|}{ Number of galls on chilli roots } \\
\hline 0 & 0.00 & 0.00 & 0.00 & 0.00 \\
\hline 1000 & 57 & 38 & 36 & 31 \\
\hline 2000 & 72 & 47 & 42 & 37 \\
\hline \multicolumn{5}{|c|}{ Number of egg masses on chilli roots } \\
\hline 0 & 0.00 & 0.00 & 0.00 & 0.00 \\
\hline 1000 & 26 & 20 & 17 & 16 \\
\hline 2000 & 34 & 26 & 20 & 17 \\
\hline \multicolumn{5}{|c|}{ Wilt free days of chilli } \\
\hline 0 & 42 & 21 & 18 & 13 \\
\hline 1000 & 42 & 19 & 15 & 11 \\
\hline 2000 & 42 & 14 & 12 & 8 \\
\hline \multicolumn{5}{|c|}{ Incidence of bacterial wilt after $\mathbf{4 2}$ days } \\
\hline 0 & 0.00 & 16.67 & 16.67 & 33.33 \\
\hline 1000 & 0.00 & 16.67 & 33.33 & 50.00 \\
\hline 2000 & 0.00 & 33.33 & 50.00 & 66.67 \\
\hline
\end{tabular}

Effect on number of galls and egg masses

Significant variations were observed in number of galls and egg masses per root system in response to both the pathogens applied individually and in combinations. Maximum numbers of galls and egg masses were observed where nematode was applied alone. Significant reductions in galls and egg masses were recorded where nematode and the bacterium were applied in combinations. At higher densities of both the pathogens, the reductions in these parameters were the maximum as shown in Table I.

\section{Effect on incidence of bacterial wilt}

The first wilt appearance was observed after 8 days in the treatment where both the pathogens were applied at their highest densities. The treatments where bacterium was applied individually at different densities, wilt took maximum days to appear as compared to the treatments where bacterium and nematodes were applied in combinations as shown in Table I. Similarly, the incidence of bacterial wilt was lower where the nematode was absent. Minimum wilt incidence was recorded at the lowest density of $R$. solanacearum. The wilt incidence increased significantly when nematode was inoculated along with the bacterium and maximum incidence was recorded where both the pathogens were applied at their highest densities as shown in Table I.

\section{DISCUSSION}

The present study showed effects of Ralstonia solanacearum and Meloidogyne javanica individually and in combination. The combined effects of both the pathogens on chili were more pronounced as compared to the effects caused by single application of the pathogens. Similar results of increased bacterial wilt severity in the presence of Meloidogyne spp. were reported by many workers (Libman et al., 1964; Jatala et al., 1975; Sitaramaiah and Sinha, 1984). The reductions in shoot length and weight at pathogenic or above pathogenic density of $M$. javanica is due to the impaired carbohydrate partitioning to the roots (Carneiro et al., 1999), mobilization and accumulation of photosynthesis products from shoots to roots during reproductive phase of adult females (Karssen and Moens, 2006). The findings confirmed the observations made by Sitaramaiah and Sinha (1984) who reported increase in reduction in plant heights in combined treatments of nematode and the bacterium in Brinjal.

Significant reductions in plant height, fresh shoot and root weights were observed in all the treatments in comparison to control. Similar findings were also reported by Napier and Quimo (1980) and Sitaramaiah and Sinha (1984) in tomato and brinjal respectively when associated 
with bacteria. The data obtained in the present investigation clearly indicated that $M$. javanica played a significant role as a predisposing factor and thus increasing the incidence of wilt. Plants which received M. javanica and $R$. solanacearum separately as well as in three different combinations, recorded significantly lower plant height, fresh and dry shoot weight and fresh and dry root weight compared to healthy plants.

The bacterial wilt incidence was the maximum in plants inoculated simultaneously with nematode and the bacterium (Table I). Treatments with bacterium alone showed a decrease in wilt incidence. Similar results were reported by Routaray et al. (1986) who found that inoculation of $M$. incognita seven days prior to $P$. solanacearum at planting caused maximum wilt followed by simultaneous inoculations of both the pathogens at 60 days of observation. No wilt was noticed in plants inoculated with nematode alone and inoculated plant showed very poor growth and chlorotic appearance. Similar results have also been reported by Haider et al. (1989) who reported that simultaneous inoculation of both the pathogens produced maximum wilt. Minimum wilt was noticed with bacterium alone. Further, Swain et al. (1987) also reported that the combined pathogenic effects of $M$. incognita and $R$. solanacearum on a resistant brinjal cultivar (Pusa purple cluster) provided synergistic effect towards the development of wilt symptoms and affected different plant growth parameters such as shoot length, shoot weight, root length and root weight. Number of galls, number of egg masses and root-knot index were the maximum for nematode treatment alone but it was significantly less in other treatments. Perhaps prior establishment of bacterial colonies in the rhizosphere was not conducive for nematode multiplication. Pitcher (1963) suggested that the bacterium modifies extensively host tissue which does not favor nematode multiplication. This could be the reason for decreased nematode multiplication in the present study. It has been known for a long time that root-knot nematode facilitates entry and establishment of pathogenic fungi and bacteria (Powell, 1971). In brinjal, the disease complex has been observed frequently involving $R$. solanacearum along with root-knot nematode contributing to an increase in wilt development (Swain et al., 1987). The combined pathogenic effects of Pseudomonas solanacearum biotype-3 and Meloidogyne javanica on brinjal were greater than independent effects of either (Ravichandra et al., 1990).

\section{CONCLUSION}

It is concluded from the present study that Meloidogyne javanica increased severity of bacterial wilt caused by Ralstonia solanacearum at all the inoculum densities. The presence of $M$. javanica in bacterial inoculated plants accelerated the development of wilt symptoms. The simultaneous inoculation of both the pathogens also resulted in increase in reductions in growth parameters of chili, therefore, stringent control measures are recommended for the management of disease complex.

Statement of conflict of interest

The authors declare there is no conflict of interest.

\section{REFERENCES}

Ashfaq, M., Saleem, A., Waqas, M. and Mukhtar, T., 2017. Natural occurrence and host range studies of cucumber mosaic virus (CMV) infecting ornamental species in the Rawalpindi-Islamabad area of Pakistan. Philipp. Agric. Scient., 100: 5561.

Aslam, M.A., Javed, K., Javed, H., Mukhtar, T. and Bashir, M.S., 2019a. Infestation of Helicoverpa armigera Hübner (Noctuidae: Lepidoptera) on soybean cultivars in Pothwar region and relationship with physico-morphic characters. Pak. J. agric. Sci., 56: 401-405.

Aslam, M.N., Mukhtar, T., Ashfaq, M. and Hussain, M.A., 2017a. Evaluation of chili germplasm for resistance to bacterial wilt caused by Ralstonia solanacearum. Australas. Pl. Pathol., 46: 289-292. https://doi.org/10.1007/s13313-017-0491-2

Aslam, M.N., Mukhtar, T., Hussain, M.A. and Raheel, M., 2017b. Assessment of resistance to bacterial wilt incited by Ralstonia solanacearum in tomato germplasm. J. Pl. Dis. Prot., 124: 585-590. https:// doi.org/10.1007/s41348-017-0100-1

Aslam, M.N., Mukhtar, T., Jamil, M. and Nafees, M., 2019b. Analysis of aubergine germplasm for resistance sources to bacterial wilt incited by Ralstonia solanacearum. Pak. J. agric. Sci., 56: 119-122.

Burney, K., Roshan, Z. and Iftikhar, A., 1999. Bacterial wilt caused by Ralstonia solanacearum in Solanaceous crops of Pakistan. Proceedings of $2^{\text {nd }}$ National Conference of Plant Pathology, pp. 27-29.

Carneiro, R.G., Mazzafera, P. and Ferraz, L.C.C.B., 1999. Carbon partitioning in soybean infected with Meloidogyne incognita and M. javanica. J. Nematol., 31: 348-355.

Elphinstone, J.G., 2005. The current bacterial wilt situation: a global overview. In: Bacterial wilt: the disease and the Ralstonia solanacearum species complex (eds. C. Allen, P. Prior, A.C. Hayward). 
American Phytopathological Society, Saint Paul, pp. 9-28.

Fateh, F.S., Mukhtar, T., Kazmi, M.R., Abbassi, N.A. and Arif, A.M., 2017. Prevalence of citrus decline in district Sargodha. Pak. J. agric. Sci., 54: 9-13. https://doi.org/10.21162/PAKJAS/17.5643

Flores-Cruz, Z. and Allen, C., 2009. Ralstonia solanacearum encounters an oxidative environment during tomato infection. Mol. Pl. Microbe Interact., 22: 773-782. https://doi.org/10.1094/MPMI-22-70773

Geddes, A.M.W., 1989. Potato Atlas of Pakistan: Information of potato production by agro ecological zones. Pak-Swiss Potato Development Project, PARC, Islamabad, Pakistan. pp. 76-77.

Haider, M.G., Nath, R.P., Thakur, S.C. and Ojha, K.L., 1989. Interaction of Meloidogyne incognita and Pseudomonas solanacearum on tomato plants. Indian J. Nematol., 17: 174-176.

Hayward, A., Allen, C. and Prior, P., 2005. Research on bacterial wilt: a perspective on international linkages and access to the literature. Bacterial wilt: the disease and the Ralstonia solanacearum species complex, 1-8.

Hayward, A.C., 1994. Systematic and phylogeny of Pseudomonas solanacearum and related bacteria. In: Bacterial wilt: The disease and its causative agent, Pseudomonas solanacearum (eds. A.C. Hayward and G.L. Hartman). CAB International, Wallingford. pp. 123-135.

Hussain, M.A. and Mukhtar, T., 2019. Root-knot nematodes infecting okra in major vegetable growing districts of Punjab, Pakistan. Pakistan J. Zool. 51:1137-1143. https://doi.org/10.17582/ journal.pjz/2019.51.3.1137.1143

Jatala, P., French, E.R. and Gutarra, L., 1975. Interrelationship of Meloidogyne incognita acrita and Pseudomonas solanacearum on potato. $J$. Nematol., 7: 325.

Javed, H., Hussain, S.S., Javed, K., Mukhtar, T. and Abbasi, N.A., 2017a. Comparative infestation of brinjal stem borer (Euzophera perticella) on six aubergine cultivars and correlation with some morphological characters. Pak. J. agric. Sci., 54: 753-758.

Javed, H., Mukhtar, T., Javed, K. and Ata ul Mohsin, 2017b. Management of eggplant shoot and fruit borer (Leucinodes orbonalis Guenee) by integrating different non-chemical approaches. Pak. J. agric. Sci., 54: 65-70. https://doi.org/10.21162/ PAKJAS/17.5282

Javed, K., Javed, H., Mukhtar, T. and Qiu, D., 2019.
Efficacy of Beauveria bassiana and Verticillium lecanii for the management of whitefly and aphid. Pak. J. agric. Sci., 56: 669-674.

Karssen, G. and Moens, M., 2006. Root-knot nematodes. In: Plant nematology (eds. R.N. Perry and M. Moens), Cabi Pub-lishing, Wallingford, UK, pp. 5990. https://doi.org/10.1079/9781845930561.0059

Kayani, M.Z. and Mukhtar, T., 2018. Reproductivity of Meloidogyne incognita on fifteen cucumber cultivars. Pakistan J. Zool., 50: 1717-1722. https:// doi.org/10.17582/journal.pjz/2018.50.5.1717.1722

Kayani, M.Z., Mukhtar, T. and Hussain, M.A., 2017. Effects of southern root knot nematode population densities and plant age on growth and yield parameters of cucumber. Crop Prot., 92: 207-212. https://doi.org/10.1016/j.cropro.2016.09.007

Kayani, M.Z., Mukhtar, T. and Hussain, M.A., 2018. Interaction between nematode inoculum density and plant age on growth and yield of cucumber and reproduction of Meloidogyne incognita. Pakistan J. Zool., 50: 897-902. https://doi.org/10.17582/ journal.pjz/2018.50.3.897.902

Khan, A.R., Javed, N., Sahi, S.T., Mukhtar, T., Khan, S.A. and Ashraf, W., 2017. Glomus mosseae (Gerd \& Trappe) and neemex reduce invasion and development of Meloidogyne incognita. Pakistan J. Zool., 49: 841-847. https://doi.org/10.17582/ journal.pjz/2017.49.3.841.847

Lambert, C., 2002. Agricultural Bioterrorism Protection Act of 2002: possession, use and transfer of biological agents and toxins; Interim and Final Rule (7CRF part 331). Fed. Reg., 67: 76908-76938.

Libman, G., Leach, J.G. and Adamas, R.E., 1964. Role of certain plant parasitic nematodes in infection of tomatoes by Pseudomona solanacearum. Phytopathology, 54: 151-153.

Mukhtar, T., 2018. Management of root-knot nematode, Meloidogyne incognita, in tomato with two Trichoderma species. Pakistan J. Zool., 50: 1589-1592. https://doi.org/10.17582/journal. pjz/2018.50.4.sc15

Mukhtar, T., Arooj, M., Ashfaq, M. and Gulzar, A., 2017a. Resistance evaluation and host status of selected green gram germplasm against Meloidogyne incognita. Crop Prot., 92: 198-202. https://doi.org/10.1016/j.cropro.2016.10.004

Mukhtar, T., Hussain, M.A. and Kayani, M.Z., 2017b. Yield responses of 12 okra cultivars to southern root-knot nematode (Meloidogyne incognita). Bragantia, 76: 108-112. https://doi. org/10.1590/1678-4499.005

Mukhtar, T., Jabbar, A., Raja, M.U. and Javed, H., 
2018. Re-emergence of wheat seed gall nematode (Anguina tritici) in Punjab, Pakistan. Pakistan J. Zool., 50: 1195-1198. https://doi.org/10.17582/ journal.pjz/2018.50.3.sc4

Napier, C.M. and Quimo, A.J., 1980. Influence of rootknot nematode on bacterial wilt severity in tomato. Annls Trop. Res., 2: 29-39.

Pitcher, R.S., 1963. Role of plant parasitic nematodes in bacterial diseases. Phytopathology, 53: 35-39.

Powell, N.T., 1971. Interaction of plant parasitic nematodes with other disease-causing agents. In: Plant parasitic nematodes (eds. B.M. Zuckerman, W.F. Mai and R.A. Rohde). Academic Press Inc., London, 2: 119-136. https://doi.org/10.1016/B9780-12-782202-0.50012-6

Ravichandra, N.G., Krishnappa, K. and Setty, K.G.H., 1990. Interaction of Meloidogyne javanica and race1, race-2, race-3 of $M$. incognita with Pseudomonas solanacearum on a few brinjal cultivar/lines. Indian J. Nematol., 20: 138-147.

Routaray, N., Sahoo, H. and Das, S.N., 1986. Response of some tomato cultivars to inoculations of Meloidogyne incognita and Pseudomonas solanacearum. Indian J. Nematol., 16: 56-59.

Sarkar, S. and Chaudhuri, S., 2015. New report of additional enterobacterial species causing wilt in West Bengal, India. Can. J. Microbiol., 61: 477486. https://doi.org/10.1139/cjm-2015-0017

Sitaramaiah, K. and Sinha, S.K., 1984. Interaction between Meloidogyne javanica and Pseudomonas solanacearum on brinjal. Indian J. Nematol., 14: 1-5.

Smith, E.F., 1920. An introduction to bacterial diseases of plants: WB Saunders. https://doi.org/10.5962/ bhl.title.41862
Swain, P.K., Rath, J.C. and Mishra, S.K., 1987. Interaction of Meloidogyne incognita and Pseudomonas solanacearum on brinjal. Indian J. Nematol., 17: 67-71.

Tariq-Khan, M., Munir, A., Mukhtar, T., Hallmann, J. and Heuer, H., 2017. Distribution of root-knot nematode species and their virulence on vegetables in northern temperate agro-ecosystems of the Pakistani-administered territories of Azad Jammu and Kashmir. J. Pl. Dis. Prot., 124: 201-212. https:// doi.org/10.1007/s41348-016-0045-9

Whitehead, A.G. and Hemming, J.R., 1965. A comparison of some quantitative methods of extracting small vermiform nematodes from soil. Annls appl. Biol., 55: 25-38. https://doi. org/10.1111/j.1744-7348.1965.tb07864.x

Wicker, E., Grassart, L., Coranson-Beaudu, R., Mian, D., Guilbaud, C., Fegan, M. and Prior, P., 2007. Ralstonia solanacearum strains from Martinique (French West Indies) exhibiting a new pathogenic potential. Appl. environ. Microbiol., 73: 67906801. https://doi.org/10.1128/AEM.00841-07

Winstead, N.N. and Kelman, A., 1952. Inoculation techniques for evaluation of resistance to Pseudomonas solanacearum. Phytopathology, 42: 628-634.

Yabuuchi, E., Kosako, Y., Yano, I., Hotta, H. and Nishiuchi, Y., 1995. Transfer of two Burkholderia and an Alcaligenes species to Ralstonia Gen. Nov.: Proposal of Ralstonia pickettii (Ralston, Palleroni and Doudoroff 1973) Comb Nov., Ralstonia solanacearum (Smith 1896) Comb. Nov. and Ralstonia eutropha (Davis 1969) Comb. Nov. Microbiol. Immunol., 39: 897-904. https://doi. org/10.1111/j.1348-0421.1995.tb03275.x 